\title{
Effect of professional certification on employees' return-to-work rate after occupational injuries in Korea: focusing on vulnerable groups
}

Suk Won Bae ${ }^{1,2}$

\begin{abstract}
Background: One effective way to improve return-to-work (RTW) performance may be to convince the employer that the worker has the necessary skills. The aim of this paper is to investigate the effect of having a professional certification among workers injured in occupational injuries on their return to work.

Methods: The Panel Study of Workers' Compensation Insurance (PSWCI) targets workers who completed medical care in 2012 after an occupational injury. The study population $(n=2000)$ was stratified by gender, age, region, disability grade, and rehabilitation service use. A total of 1458 workers were finally selected for this study. The effect of having a certification on RTW status was calculated with an odds ratio and 95\% confidence intervals using binomial and multinomial logistic regression analyses. In the binomial logistic regression analysis, the RTW group was made up as a combination of the return to original work and the reemployment groups.
\end{abstract}

Results: The ORs of RTW among those with a certification compared to those without certification were 1.38 (1.161.65) in Model 1, $1.25(1.05-1.50)$ in Model 2, and $1.22(1.01-1.47)$ in Model 3. Among female workers with a certification, the OR of RTW was 4.60 (2.68-7.91), that of return to original work was 3.21 (1.74-5.91), and that of reemployment was 5.85 (3.34-10.27). Among daily workers with a certification, the OR of RTW was 1.32 (1.03-1.69) and that of reemployment was 1.37 (1.07-1.76).

Conclusion: In conclusion, injured workers with a certification generally had a higher RTW rate. In particular, the RTW rate was higher among female workers and daily workers with a certification than among those without.

Keywords: Occupational injury, Workers' compensation insurance, Return to work, Certification

\footnotetext{
Correspondence: swbae@yuhs.ac

${ }^{1}$ Department of Public Health, Graduate School, Yonsei University, 50

Yonsei-ro, Seodaemun-gu, Seoul 03722, Republic of Korea

${ }^{2}$ The Institute for Occupational Health, Yonsei University College of Medicine,

Seoul 03722, Republic of Korea
}

C The Author(s). 2021 Open Access This article is licensed under a Creative Commons Attribution 4.0 International License, which permits use, sharing, adaptation, distribution and reproduction in any medium or format, as long as you give appropriate credit to the original author(s) and the source, provide a link to the Creative Commons licence, and indicate if changes were made. The images or other third party material in this article are included in the article's Creative Commons licence, unless indicated otherwise in a credit line to the material. If material is not included in the article's Creative Commons licence and your intended use is not permitted by statutory regulation or exceeds the permitted use, you will need to obtain permission directly from the copyright holder. To view a copy of this licence, visit http://creativecommons.org/licenses/by/4.0/. The Creative Commons Public Domain Dedication waiver (http://creativecommons.org/publicdomain/zero/1.0/) applies to the data made available in this article, unless otherwise stated in a credit line to the data. 


\section{Introduction}

The Korean Ministry of Employment and Labor reported in 2018 that the number of occupational injured workers who consequently required the minimum 4 days of leave was approximately 100,000 [1]. This figure represents about $0.54 \%$ of 19 million workers who were eligible for Workers' Compensation Insurance [1]. Even though this figure increased from 2017 to 2018, the overall trend of occupational injured workers has decreased [2]. However, regardless of such slight rises and falls, the total number of injured workers remains at a high level $[1,2]$. In addition, the economic loss due to occupational injuries is significant $[3,4]$. The direct compensation provided for occupational injuries was estimated at KRW 5 trillion (4.4 billion USD), and the estimated total economic loss, including indirect compensation, was KRW 25 trillion (21.8 billion USD) [1, 3]. Furthermore, workforce loss due to occupational injuries and economic losses are closely related [4-7].

Korea has implemented the Industrial Accident Compensation Insurance Act to provide prompt and fair compensation and support for rehabilitation and social return of disaster workers in the wake of a disaster [4]. The Korean Workers' Compensation and Welfare Service (KCOMWEL) provides disability benefits to injured workers to compensate for the loss of income due to an accident $[8,9]$. For individuals who are injured and not working, receiving immediate financial support and rehabilitation is critical. However, these forms of primary support are not enough to ensure employees maintain their previous work performance levels after the accident. The accident causes injured workers not only to lose the ability to work but also to experience loss of self-esteem and self-efficacy and depression, which hinders their return-to-work (RTW) rate [4, 10-15].

Several studies have identified factors affecting the RTW rate of injured workers [16-19]. These factors can be divided into five categories: personal, socioeconomic, occupational, degree of injury, and employer interest level in workers' reemployment $[4,16,19]$. RTW is known to be associated with personal factors such as being male, being younger, being married, having a higher education level, and having a higher household income [18] and occupational factors such as larger-sized workplaces, longer duration of employment, regular workers, and other factors such as lower disability ratings after occupational injuries, shorter length of hospital stays and recovery duration, hospitals with higher quality scores, and greater interest of doctors in charge and employers in injured workers' RTW $[20,21]$. However, the above factors are outside the individual's control and are hard to change even if the workers have strong will to RTW. Thus, it is necessary to study the factors within injured workers' control that can positively affect RTW to assist in their RTW preparation.
One effective way to improve RTW performance is to convince the employer that the worker has the necessary skills. Professional certification in the field is often used as an official permit for performing a job [22, 23], and it can provide employers an objective evaluation of employees' skills [22, 24]. Therefore, it has been recognized as a useful resource to help someone get a job [25-27]. It is possible that as an indicator of skills, professional certification could assist injured workers who want to RTW.

Most studies on occupational injuries focused on RTW $[9,18,19]$. However, few have examined the relationship between workers' RTW and professional certification. Therefore, this study investigates the effect of professional certification on injured workers' RTW after occupational injuries.

\section{Materials and methods}

\section{Study design and participants}

In this study, we used data from the first cohort (firstfifth waves) survey of the Panel Study of Workers' Compensation Insurance (PSWCI) conducted by the Korea Workers' Compensation and Welfare Service (KCOMWEL). The PSWCI provides useful data on all policy processes related to Industrial Accident Compensation Insurance Act, including those involving injured workers returning to work. The PSWCI targets workers who completed medical care in 2012 after an occupational injury $(n=82,493)$; the study population $(n=2000)$ was stratified by gender, age, region, disability grade, and rehabilitation service use.

Since the first survey in 2013, the PSWCI has been conducted annually. The fifth wave was completed in 2017. The study methods comprised one-to-one interviews conducted by professional interviewers who visited the participants; participants were asked to respond to the questionnaire in person $[4,28-32]$.

Of the total 2000 participants in the first cohort survey, 1616 participated. Participants who had participated in the first-fifth waves were included in the present study. One hundred and two workers who had not continuously participated in the first-fifth waves were excluded. In addition, five workers who were selfemployed or employers at the time of the occupational injury and 51 injured workers whose explanatory variables were not observed were also excluded. Therefore, a total of 1458 workers were finally selected for this study (Fig. 1).

\section{Sociodemographic characteristics}

Age was classified into five groups: <30, 30-39, 40-49, $50-59$, and $\geq 60$ years. Marital status was classified into three groups: "not married," "married," and "other" (separated, divorced, widowed). Education level was classified 


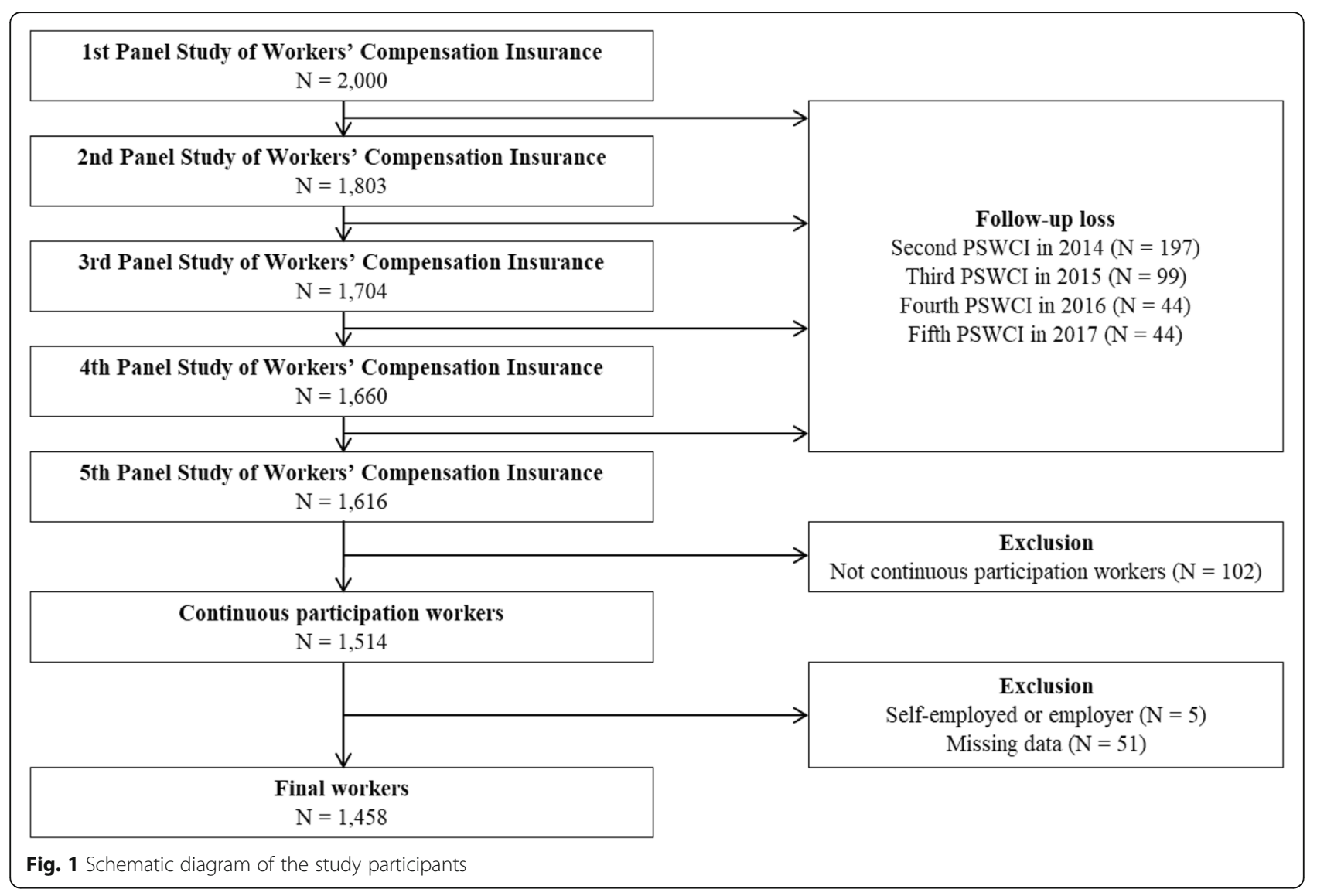

into three groups: "below high school graduate," "high school graduate," and "college graduate or above."

\section{Occupational-related characteristics}

Occupational factors included industry sector, status of workers, number of employees, and duration of employment in the workplace at the time of occupational injury.

Industry sector was categorized according to the Korean Standard Industry Classification (KSIC) (based on the International Standard Industry Classification, ISIC) into "manufacturing" and "construction"-which accounted for more than half of occupational injuries and diseases (manufacturing: 26.8\%, construction: $27.1 \%$ in 2018 [1]) - and "services (Information and communications; professional, scientific and technical activities, etc.)" and "other (Agriculture, forestry and fishing; Mining and quarrying, etc.)."

For worker status, full-time workers were classified as "regular workers," whereas temporary and daily workers were classified as "daily workers." The "number of employees in the workplace" was divided into four groups: $<5,5-9,10-29$, and $\geq 30$. The "duration of employment at the workplace" was divided into three groups: $<1$ year, $1-3$ years, and $\geq 3$ years.

\section{Injury-related characteristics}

Data on occupational injury type and disability rating were obtained from the KCOMWEL's administrative database. The type of occupational injury was classified into injuries and diseases. If workers suffered any mental or physical disability from occupational-related injuries or diseases and met the requirements for industrial accident compensation, they were assigned a disability rating from Grades 1 to 14 under the Korean Industrial Accident Compensation Insurance Act. A grade close to Grade 1 indicates a more serious disability [4, 28]. Occupational injuries were classified into three categories: 1-7 (severe), 8-14 (moderate), and "none."

\section{Qualifications-related characteristics}

We investigated whether participants held any national certification (professional engineer, engineer, master craftsman, industrial engineer, craftsman, or other national certification), private degrees, or international (foreign) certificates (excluding general driving license). In the first wave of the panel study, participants with one or more certifications were coded as "yes," and those with no certification were coded as "no." 
Table 1 General characteristics of participants by return-to-work rate

\begin{tabular}{|c|c|c|c|c|c|c|c|c|}
\hline & Retu & al work & Reer & & Non & & Total & $P$ value * \\
\hline & $N$ & $\%$ & $N$ & $\%$ & $N$ & $\%$ & & \\
\hline Total & 556 & 38.1 & 747 & 51.2 & 155 & 10.6 & 1458 & $<0.0001$ \\
\hline Age & & & & & & & & $<0.0001$ \\
\hline$<30$ & 29 & 35.4 & 44 & 53.7 & 9 & 11.0 & 82 & \\
\hline $30-39$ & 103 & 49.5 & 95 & 45.7 & 10 & 4.8 & 208 & \\
\hline $40-49$ & 170 & 46.8 & 177 & 48.8 & 16 & 4.4 & 363 & \\
\hline $50-59$ & 191 & 36.5 & 279 & 53.2 & 54 & 10.3 & 524 & \\
\hline$\geq 60$ & 63 & 22.4 & 152 & 54.1 & 66 & 23.5 & 281 & \\
\hline Sex & & & & & & & & 0.0002 \\
\hline Male & 472 & 39.2 & 621 & 51.6 & 110 & 9.1 & 1203 & \\
\hline Female & 84 & 32.9 & 126 & 49.4 & 45 & 17.7 & 255 & \\
\hline Marital status & & & & & & & & 0.0001 \\
\hline Not married & 73 & 35.8 & 112 & 54.9 & 19 & 9.3 & 204 & \\
\hline Married & 436 & 41.3 & 510 & 48.3 & 110 & 10.4 & 1056 & \\
\hline Other & 47 & 23.7 & 125 & 63.1 & 26 & 13.1 & 198 & \\
\hline Education level & & & & & & & & $<0.0001$ \\
\hline Less than high school & 161 & 27.1 & 340 & 57.1 & 94 & 15.8 & 595 & \\
\hline High school & 284 & 44.6 & 306 & 48.0 & 47 & 7.4 & 637 & \\
\hline College or above & 111 & 49.1 & 101 & 44.7 & 14 & 6.2 & 226 & \\
\hline Industry & & & & & & & & $<0.0001$ \\
\hline Manufacturing & 267 & 48.1 & 243 & 43.8 & 45 & 8.1 & 555 & \\
\hline Construction & 59 & 15.3 & 274 & 71.0 & 53 & 13.7 & 386 & \\
\hline Service & 88 & 47.6 & 80 & 43.2 & 17 & 9.2 & 185 & \\
\hline Other & 142 & 42.8 & 150 & 45.2 & 40 & 12.1 & 332 & \\
\hline Status of workers & & & & & & & & $<0.0001$ \\
\hline Regular worker & 449 & 55.3 & 311 & 38.3 & 52 & 6.4 & 812 & \\
\hline Daily worker & 107 & 16.6 & 436 & 67.5 & 103 & 15.9 & 646 & \\
\hline Occupational injury type & & & & & & & & 0.0088 \\
\hline Injury & 493 & 37.0 & 698 & 52.3 & 143 & 10.7 & 1334 & \\
\hline Disease & 63 & 50.8 & 49 & 39.5 & 12 & 9.7 & 124 & \\
\hline Number of employees & & & & & & & & $<0.0001$ \\
\hline$<5$ & 106 & 31.6 & 184 & 54.9 & 45 & 13.4 & 335 & \\
\hline $5-9$ & 100 & 29.1 & 211 & 61.3 & 33 & 9.6 & 344 & \\
\hline $10-29$ & 136 & 34.5 & 218 & 55.3 & 40 & 10.2 & 394 & \\
\hline$\geq 30$ & 214 & 55.6 & 134 & 34.8 & 37 & 9.6 & 385 & \\
\hline Duration of employment & & & & & & & & $<0.0001$ \\
\hline$<1$ year & 217 & 23.3 & 595 & 64.0 & 118 & 12.7 & 930 & \\
\hline 1-less than 3 years & 88 & 46.3 & 85 & 44.7 & 17 & 9.0 & 190 & \\
\hline$\geq 3$ years & 251 & 74.3 & 67 & 19.8 & 20 & 5.9 & 338 & \\
\hline Disability rating & & & & & & & & $<0.0001$ \\
\hline $1-7$ & 18 & 29.5 & 22 & 36.1 & 21 & 34.4 & 61 & \\
\hline 8-14 & 430 & 37.8 & 594 & 52.2 & 114 & 10.0 & 1138 & \\
\hline None & 108 & 41.7 & 131 & 50.6 & 20 & 7.7 & 259 & \\
\hline
\end{tabular}


Table 1 General characteristics of participants by return-to-work rate (Continued)

\begin{tabular}{|c|c|c|c|c|c|c|c|c|}
\hline & \multicolumn{2}{|c|}{ Returned to original work } & \multicolumn{2}{|c|}{ Reemployed } & \multicolumn{2}{|c|}{ Non-RTW } & \multirow[t]{2}{*}{ Total } & \multirow[t]{2}{*}{$P$ value * } \\
\hline & $\bar{N}$ & $\%$ & $\bar{N}$ & $\%$ & $\bar{N}$ & $\%$ & & \\
\hline Certification & & & & & & & & 0.0001 \\
\hline Yes & 255 & 42.7 & 300 & 50.3 & 42 & 7.0 & 597 & \\
\hline No & 301 & 35.0 & 447 & 51.9 & 113 & 13.1 & 861 & \\
\hline
\end{tabular}

${ }^{*}$ Analyses using a chi-square test

\section{Main outcome variables}

The type of economic activity included return to original work, reemployment, self-employment, unpaid family work, unemployed, or economically inactive. Those who returned to their original work were workers who were injured at the workplace, but resumed work in the same position they held at the time of injury. Workers who found paid employment in a workplace other than where they experienced the injury were referred to as reemployed workers. Self-employed workers included private business owners or freelancers, and unpaid family workers referred to those who helped their family or relatives in the workplace for an average of $>18 \mathrm{~h}$ per week (more than 3-4h per day). Unemployed persons referred to those who reported searching for a job more than once during the past 4 weeks and were able to work if they found a suitable job during the last 1 week; those who did not were classified as an "economically inactive population [20]."

In this study, the type of economic activity was classified as "return to original work," reemployed and selfemployed persons as "reemployed," and unpaid family workers, the unemployed, and the economically inactive population as "non-return-to-work" (non-RTW).

\section{Statistical analyses}

The characteristics of the participants regarding work status, and of those who returned to work with a certification, were analyzed using a chi-square test. The effect of having a certification on RTW status was calculated with an odds ratio (ORs) and 95\% confidence intervals using binomial and multinomial logistic regression analyses. In the binomial logistic regression analysis, the RTW group was combined with the "return to original work" group and the "reemployed" group. In the multinomial logistic regression analysis, the non-RTW group was compared with the "return to original work" group and the "reemployed" group. All analyses were performed using the software SAS statistical package version 9.4 (SAS Institute, Cary, NC, USA).

\section{Results}

The general participant characteristics according to RTW status are shown in Table 1 . The return-to- original-work rate after occupational injuries was $38.1 \%$, the reemployment rate was $51.2 \%$, and the unemployment rate was $10.6 \%(P<0.0001)$. The reemployment rates among male and female workers $(51.6 \%$ and $49.4 \%$, respectively) were higher than those for other RTW status $(P=0.0002)$. Regarding worker status, regular workers were found to have a higher rate of return to original work, whereas daily workers were found to have a higher reemployment rate $(P<0.0001)$. Those with a certification had a $42.7 \%$ return-to-original-work rate and a $50.3 \%$ reemployment rate $(P=0.0001)$.

The general characteristics of RTW workers were based on whether they held a certification (Table 2). The RTW rate among those with a certification was 93.0\%, whereas the RTW rate among those without a certification was $86.9 \%(P<0.0001)$. Overall, the RTW rate was higher among those with a certification except for those aged less than 30, with a marital status of "other," educational level of "College graduate or above," occupational injury type of "Disease," duration of employment of 1-3 years, and disability rating of Grades 1-7.

Tables 3 and 4 show the ORs of RTW according to whether the participant had a certification. Model 1 was adjusted for gender and age. In Model 2, adjustments were made for the variables in Model 1 plus marital status, educational level, type of industry, worker status, number of employees, and duration of employment. Model 3 was adjusted for the variables in Model 2 plus disability rating and type of occupational injury. The ORs of RTW among those with a certification compared to those without certification were 1.38 (1.16-1.65) in Model 1, 1.25 (1.05-1.50) in Model 2, and 1.22 (1.011.47) in Model 3 (Table 3).

The OR of return to original work among those with a certification was $1.47(1.22-1.77)$ in Model 1, while no significant result was found in Models 2 and 3. The ORs of reemployment among those with a certification were 1.33 (1.11-1.59) in Model 1, 1.30 (1.08-1.57) in Model 2 , and 1.26 (1.04-1.52) in Model 3 (Table 4).

Table 5 shows the ORs of RTW based on having a certification, which was stratified by age and status of workers. Among female workers with a certification, the OR of RTW was 4.60 (2.68-7.91), that of return to original work was 3.21 (1.74-5.91), and that of reemployment was 5.85 (3.34-10.27). Among daily workers with 
Table 2 General characteristics of workers' return-to-work rate by certification

\begin{tabular}{|c|c|c|c|c|c|c|}
\hline & Yes & & No & & Total & $P$ value * \\
\hline & $N$ & $\%$ & $N$ & $\%$ & & \\
\hline Total & 555 & 93.0 & 748 & 86.9 & 1303 & $<0.0001$ \\
\hline Age & & & & & & $<0.0001$ \\
\hline$<30$ & 35 & 83.3 & 38 & 95.0 & 73 & \\
\hline $30-39$ & 113 & 94.2 & 85 & 96.6 & 198 & \\
\hline $40-49$ & 184 & 96.8 & 163 & 94.2 & 347 & \\
\hline $50-59$ & 173 & 92.0 & 297 & 88.4 & 470 & \\
\hline$\geq 60$ & 50 & 87.7 & 165 & 73.7 & 215 & \\
\hline Sex & & & & & & $<0.0001$ \\
\hline Male & 501 & 93.1 & 592 & 89.0 & 1093 & \\
\hline Female & 54 & 91.5 & 156 & 79.6 & 210 & \\
\hline Marital status & & & & & & $<0.0001$ \\
\hline Not married & 96 & 88.9 & 89 & 82.8 & 185 & \\
\hline Married & 414 & 95.0 & 532 & 90.7 & 946 & \\
\hline Other & 45 & 84.9 & 127 & 95.1 & 172 & \\
\hline Education level & & & & & & $<0.0001$ \\
\hline Less than high school & 122 & 89.1 & 379 & 82.8 & 501 & \\
\hline High school & 299 & 94.6 & 291 & 90.7 & 590 & \\
\hline College or above & 134 & 93.1 & 78 & 95.1 & 212 & \\
\hline Industry & & & & & & 0.0101 \\
\hline Manufacturing & 212 & 95.1 & 298 & 89.8 & 510 & \\
\hline Construction & 139 & 91.5 & 194 & 82.9 & 333 & \\
\hline Service & 91 & 94.8 & 77 & 86.5 & 168 & \\
\hline Other & 113 & 89.7 & 179 & 86.9 & 292 & \\
\hline Status of workers & & & & & & 0.0019 \\
\hline Regular worker & 351 & 95.1 & 409 & 92.3 & 760 & \\
\hline Daily worker & 204 & 89.5 & 339 & 81.1 & 543 & \\
\hline Occupational injury type & & & & & & 0.2083 \\
\hline Injury & 501 & 93.3 & 690 & 86.6 & 1191 & \\
\hline Disease & 54 & 90.0 & 58 & 90.6 & 112 & \\
\hline Number of employees & & & & & & 0.0043 \\
\hline$<5$ & 106 & 93.0 & 184 & 83.3 & 290 & \\
\hline $5-9$ & 118 & 93.7 & 193 & 88.5 & 311 & \\
\hline $10-29$ & 169 & 93.4 & 185 & 86.9 & 354 & \\
\hline$\geq 30$ & 162 & 92.1 & 186 & 89.0 & 348 & \\
\hline Duration of employment & & & & & & 0.0038 \\
\hline$<1$ year & 324 & 92.1 & 488 & 84.4 & 812 & \\
\hline 1-less than 3 years & 70 & 89.7 & 103 & 92.0 & 173 & \\
\hline$\geq 3$ years & 161 & 96.4 & 157 & 91.8 & 318 & \\
\hline Disability rating & & & & & & 0.0662 \\
\hline $1-7$ & 10 & 52.6 & 30 & 71.4 & 40 & \\
\hline $8-14$ & 445 & 94.5 & 579 & 86.8 & 1024 & \\
\hline None & 100 & 93.5 & 139 & 91.5 & 239 & \\
\hline
\end{tabular}

\footnotetext{
${ }^{*}$ Analyses using a chi-square test
} 
Table 3 Odds ratios of return-to-work rate by certification

\begin{tabular}{|c|c|c|c|c|c|c|c|c|}
\hline & \multicolumn{8}{|c|}{ Return-to-work* } \\
\hline & \multicolumn{3}{|c|}{ Model 1} & \multicolumn{3}{|c|}{ Model 2} & \multicolumn{2}{|c|}{ Model 3} \\
\hline & OR & $95 \% \mathrm{Cl}$ & & OR & $95 \% \mathrm{Cl}$ & & OR & $95 \% \mathrm{Cl}$ \\
\hline \multicolumn{9}{|c|}{ Certification } \\
\hline Yes & 1.38 & $1.16-$ & -1.65 & 1.25 & $1.05-$ & -1.50 & 1.22 & $1.01-1.47$ \\
\hline No & 1.00 & & & 1.00 & & & 1.00 & \\
\hline
\end{tabular}

*Returned to original work group and reemployed group were integrated into RTW group

Model 1: Adjusted for age and sex

Model 2: Adjusted for Model $1+$ marital status, education level, industry,

status of workers, number of employees, and duration of employment

Model 3: Adjusted for Model $2+$ disability rating and occupational injury type

a certification, the OR of RTW was $1.32(1.03-1.69)$ and that of reemployment was 1.37 (1.07-1.76).

\section{Discussion}

This study investigated the effects of holding a certification on RTW among occupationally injured workers after completion of medical care.

The ORs of RTW (4.60, 2.68-7.91), return to original work (3.21, 1.74-5.91), and reemployment (5.85, 3.3410.27) among female workers with a certification were higher than in those with no certification. In addition, the ORs of RTW (1.32, 1.03-1.69) and reemployment (1.37, 1.07-1.76) among daily workers with a certification were higher than those with no certification (Table 5). Thus, the effect of having a certification on RTW is greater among female workers and daily workers who were relatively more vulnerable to a lower RTW rate than male workers and full-time workers, who are known to have a high RTW rate. This finding is consistent to the results of a previous study, which reported that having a certification had a positive effect (Coef. 1.468) on employment among vulnerable groups [27]. We therefore believe that having a certification is crucial for RTW in injured workers, especially those belonging to vulnerable groups.

Among sociodemographic factors, a higher educational level was found to be associated with a higher return-tooriginal-work rate. In terms of occupational factors, the return-to-original-work rate was higher among those who were in manufacturing industries, those who are regular workers, those whose workplace had more than 30 employees at the time of the occupational injury, and those who had worked for more than 3 years at the workplace where the occupational injury occurred. In terms of injury-related factors, non-disability or a lower disability grade was associated with a higher return-tooriginal-work rate (Table 1). This is consistent with previous findings in that the rate of return to original work was higher among students with high school graduation or more, manufacturing workers, regular and full-time workers, workers of workplaces with at least $50 \mathrm{em}$ ployees at the time of occupational injury, workers whose duration of employment at the workplace at the time of occupational injury was 1 year or longer, and workers with no disability or with grade 10-14 disability [33-37]. In particular, the return-to-original-work rate among construction workers after an occupational injury was lower than among manufacturing and service workers. This was likely due to a higher percentage of daily workers in the construction industry than in the manufacturing and service industries $[4,38]$. In addition, most construction workers were older and thus more likely to have a disability after a workplace accident [4].

With regard to the association between RTW and holding a certification, the RTW rate among workers with a certification was higher than among those without a certification (Table 2). The ORs of RTW among those with a certification were higher in Model 1 (1.38, 1.16-1.65), Model 2 (1.25, 1.05-1.50), and Model 3 (1.22, 1.01-1.47), indicating that the ORs of RTW in all models were higher among those with a certification, compared to those without one (Table 3). In addition, the OR of return to original work was $1.47(1.22-1.77)$ in Model 1 (Table 4). This is consistent with the finding that RTW rate was higher among workers with a certification than among those without a certification [22, 2426]. Therefore, it is clear that having a certification can affect RTW among injured workers. Although the KCOMWEL provides injured workers with customized rehabilitation support services across stages of medical care to facilitate their RTW and help the community at large [1-3], no support is offered for acquiring

Table 4 Odds ratios of return-to-work rate (return to original work, reemployed) by certification

\begin{tabular}{|c|c|c|c|c|c|c|c|c|c|c|c|c|c|c|c|c|c|c|c|c|c|c|c|}
\hline & \multicolumn{12}{|c|}{ Returned to original work * } & \multicolumn{11}{|c|}{ Reemployed * } \\
\hline & \multicolumn{4}{|c|}{ Model 1} & \multicolumn{4}{|c|}{ Model 2} & \multicolumn{4}{|c|}{ Model 3} & \multicolumn{4}{|c|}{ Model 1} & \multicolumn{4}{|c|}{ Model 2} & \multicolumn{3}{|c|}{ Model 3} \\
\hline & OR & $95 \%$ & & & OR & $95 \%$ & & & OR & $95 \%$ & & & OR & $95 \%$ & & & OR & $95 \%$ & & & $\mathrm{OR}$ & $95 \% \mathrm{Cl}$ & \\
\hline \multicolumn{24}{|c|}{ Certification } \\
\hline Yes & 1.47 & 1.22 & - & 1.77 & 1.15 & 0.94 & - & 1.40 & 1.12 & 0.91 & - & 1.37 & 1.33 & 1.11 & - & 1.59 & 1.30 & 1.08 & - & 1.57 & 1.26 & $1.04-$ & -1.52 \\
\hline No & 1.00 & & & & 1.00 & & & & 1.00 & & & & 1.00 & & & & 1.00 & & & & 1.00 & & \\
\hline
\end{tabular}

*Compared non-RTW group with returned to original work group and reemployed group separately

Model 1: Adjusted for age, sex

Model 2: Adjusted for Model 1 + marital status, education level, industry, status of workers, number of employees, duration of employment

Model 3: Adjusted for Model $2+$ disability rating, occupational injury type 
Table 5 Odds ratio of return-to-work rate by certification (stratified analysis)

\begin{tabular}{|c|c|c|c|c|c|c|c|c|c|c|c|c|c|}
\hline & & \multirow{2}{*}{\multicolumn{4}{|c|}{$\frac{\text { Binomial * }}{\text { Return-to-work }}$}} & \multicolumn{8}{|c|}{ Multinomial † } \\
\hline & & & & & & \multicolumn{4}{|c|}{ Returned to original work } & \multicolumn{4}{|c|}{ Reemployed } \\
\hline & & OR $\neq$ & $95 \% \mathrm{C}$ & & & $\mathrm{OR} \neq$ & $95 \%$ & & & $\mathrm{OR} \neq$ & $95 \%$ & & \\
\hline \multirow[t]{8}{*}{ Sex } & \multicolumn{13}{|l|}{ Male } \\
\hline & \multicolumn{13}{|c|}{ Certification } \\
\hline & Yes & 0.92 & 0.74 & - & 1.13 & 0.89 & 0.71 & - & 1.13 & 0.93 & 0.75 & - & 1.16 \\
\hline & No & 1.00 & & & & 1.00 & & & & 1.00 & & & \\
\hline & \multicolumn{13}{|l|}{ Female } \\
\hline & \multicolumn{13}{|c|}{ Certification } \\
\hline & Yes & 4.60 & 2.68 & - & 7.91 & 3.21 & 1.74 & - & 5.91 & 5.85 & 3.34 & - & 10.27 \\
\hline & No & 1.00 & & & & 1.00 & & & & 1.00 & & & \\
\hline \multirow[t]{8}{*}{ Status of workers } & \multicolumn{13}{|c|}{ Regular worker } \\
\hline & \multicolumn{13}{|c|}{ Certification } \\
\hline & Yes & 1.05 & 0.78 & - & 1.42 & 0.97 & 0.71 & - & 1.32 & 1.09 & 0.79 & - & 1.49 \\
\hline & No & 1.00 & & & & 1.00 & & & & 1.00 & & & \\
\hline & \multicolumn{13}{|c|}{ Daily worker } \\
\hline & \multicolumn{13}{|c|}{ Certification } \\
\hline & Yes & 1.32 & 1.03 & - & 1.69 & 1.13 & 0.84 & - & 1.54 & 1.37 & 1.07 & - & 1.76 \\
\hline & No & 1.00 & & & & 1.00 & & & & 1.00 & & & \\
\hline
\end{tabular}

* Return to original work group and reemployed group were integrated into the RTW group

†The non-RTW group was separate compared with the return to original work group and reemployed group

\#Statistical data estimated from a binomial/multinomial multivariate logistic regression analyses that adjusted for all other covariates excluding an

interesting variant

certification. We recommend that, as with vocational training support and employment support for injured workers, additional certification support should also be provided.

\section{Limitation and strength of the study}

This study has several strengths. First, it is significant in that the results provide comprehensive data on various situations and needs of injured workers because they deal extensively with RTW and socioeconomic characteristics of injured workers. In addition, data from the only panel study in South Korea that includes occupationally injured workers were used. Second, the study examined the relationship between having a professional qualification and RTW and, for the first time, attempted to investigate the relationship among injured Korean workers.

The limitations of the study were as follows. In the PSWCI, eight types of certifications (national, private, and international) were surveyed. However, as the number of persons with each type of certification was low, separate analysis regarding the effects of each type was not feasible. Therefore, analysis was performed based only on whether someone had a certification. However, RTW among injured workers may have been affected by certification type. The data used in this study were classified according to the "Yes" or "No" of a certificate in the first wave of the PSWCI. The PSWCI did not investigate the year of obtaining a certificate, so they may have obtained a certificate after an occupational injury. The time of obtaining the certificate could affect the return-to-work date. In addition, as the analysis was based on PSWCI data obtained through household interviews during a specific period, recall bias is possible $[4,28,30,32]$.

\section{Conclusions}

In conclusion, injured workers with a certification generally had a higher RTW rate. In particular, the RTW rate was higher among female workers and daily workers with a certification than among those without. This implies that having a certification may play a more important role in RTW among female workers and daily workers, who were relatively vulnerable to lower RTW rates. Therefore, strategies are needed to assist injured workers, especially those belonging to vulnerable groups, in obtaining certifications that facilitate their RTW.

\section{Acknowledgements}

The authors would like to thank the Labor Welfare Research Center of Korea Workers' Compensation and Welfare Service for making this study possible by providing the data from the Panel Study of Worker's Compensation Insurance. 


\section{Author's contributions}

SWB did the conceptualization, data collection and curation, data analysis and interpretation, funding acquisition, project administration, and writing of the original draft, review, and editing. The author read and approved the final manuscript.

\section{Funding}

This study received no funding.

\section{Availability of data and materials}

No data available.

\section{Ethics approval and consent to participate}

The data obtained the National Statistical Office's national approval statistics qualification (Approval number: 439001).

\section{Consent for publication}

Not applicable.

\section{Competing interests}

The authors declare that they have no competing interests.

Received: 2 September 2020 Accepted: 27 December 2020

Published online: 12 January 2021

\section{References}

1. Ministry of Employment and Labor (KR): Analysis of occupational accidents 2018. http://www.moel.go.kr/policy/policydata/view.do?bbs_seq=201912 00830 (2020).

2. Ministry of Employment and Labor (KR): Analysis of occupational accidents 2017. http://www.moel.go.kr/policy/policydata/view.do?bbs_seq=201903 00037 (2019). Accessed January 20.

3. Korea Workers' Compensation \& Welfare Service: 2018 Statistics of Korea Workers' Compensation and Welfare Service. https://www.kcomwel.or.kr/ kcomwel/info/data/stat/stat.jsp (2019). Accessed January 20.

4. Bae SW, Oh SS, Park WM, Roh J, Won J-U. Changes in income after an industrial accident according to industry and return-to-work status. International journal of environmental research and public health. 2019;16: 2603.

5. Haupt Theo C, Pillay K. Investigating the true costs of construction accidents. Journal of Engineering, Design and Technology. 2016;14:373-419. https://doi.org/10.1108/JEDT-07-2014-0041.

6. Leigh JP. Economic burden of occupational injury and illness in the United States. The Milbank quarterly. 2011;89:728-72. https://doi.org/10.1111/j.14680009.2011.00648.x

7. Dong XS, Wang X, Largay JA, Sokas R. Economic consequences of workplace injuries in the United States: findings from the National Longitudinal Survey of Youth (NLSY79). American journal of industrial medicine. 2016;59:106-18. https://doi.org/10.1002/ajim.22559.

8. Jeong I, Park JB, Kim HR, Yoon JH, Won JU, Roh J. Impacts of return-to-work type and period on job retention in workers with occupational injuries and diseases. J Korean Med Sci. 2018;33:e2-e. doi:10.3346/jkms.2018.33.e2.

9. Park SK. Associations of demographic and injury-related factors with return to work among job-injured workers with disabilities in South Korea. Journal of rehabilitation medicine. 2012;44:473-6. https://doi.org/10. 2340/16501977-0907.

10. Chung YK, Park CY. The effects of injury and accidents on self-rated depression in male municipal firefighters. Safety and Health at Work. 2011;2: 158-168. doi:https://doi.org/https://doi.org/10.5491/SHAW.2011.2.2.158.

11. Choi K-S, Kang S-K. Occupational psychiatric disorders in Korea. J Korean Med Sci. 2010;25:587-93.

12. Asfaw A, Souza K. Incidence and cost of depression after occupational injury. J Occup Environ Med. 2012;54:1086-91. https://doi.org/10.1097/JOM. 0b013e3182636e29.

13. Kim J Depression as a psychosocial consequence of occupational injury in the US working population: findings from the medical expenditure panel survey. BMC Public Health. 2013;13:303-. doi:10.1186/1471-2458-13-303.

14. Brown LP, Rospenda KM, Sokas RK, Conroy L, Freels S, Swanson NG. Evaluating the association of workplace psychosocial stressors with occupational injury, illness, and assault. J Occup Environ Hyg. 2011;8:31-7. https://doi.org/10.1080/15459624.2011.537985.
15. Jeong I, Yoon JH, Roh J, Rhie J, Won JU. Association between the return-towork hierarchy and self-rated health, self-esteem, and self-efficacy. International archives of occupational and environmental health. 2019;92: 709-16. https://doi.org/10.1007/s00420-019-01406-7.

16. Rhie J, Jeong I, Won JU. Return-to-work according to impairment type among occupationally injured workers in Korea. J Korean Med Sci. 2013;28: 1581-6. https://doi.org/10.3346/jkms.2013.28.11.1581.

17. Seyedmehdi M, Attarchi M, Ghaffari M, Mohammadi S, Darnahal M, Sadeghi Z. Prognostic factors for return to work after low-back disc herniation surgery. Asia-Pacific journal of public health. 2015;27:Np1775-84. doi:10. 1177/1010539512471072.

18. Berecki-Gisolf J, Clay FJ, Collie A, McClure RJ. The impact of aging on work disability and return to work: insights from workers' compensation claim records. J Occup Environ Med. 2012;54:318-27. https://doi.org/10.1097/JOM. Ob013e31823fdf9d.

19. Lee J, Choi M, Park SH, Kim H-R, Lee H-E. The effects of individual, occupational, and supportive factors on successful return to work using a structural equation model. Ann Occup Environ Med. 2015;27:21-. doi:10. 1186/s40557-015-0070-3.

20. Lee W, Yoon J-H, Roh J, Kim Y-K, Seok H, Lee J-H, et al. Factors related to the physician and the employer influencing successful return to work in Korea: results from the First Panel Study of Workers' Compensation Insurance (PSWCI). Ann Occup Environ Med. 2015;27. https://doi.org/10. 1186/s40557-015-0076-x.

21. Won JU, Seok H, Rhie J, Yoon JH. Hospital qualities related to return to work from occupational injury after controlling for injury severity as well as occupational characteristics. J Korean Med Sci. 2016;31:695-701. https://doi. org/10.3346/jkms.2016.31.5.695.

22. Sharma DS. The association between ISO 9000 certification and financia performance. The international journal of accounting. 2005;40:151-72.

23. Holland B. A workforce development systems model for unemployed job seekers. Journal of Adult and Continuing Education. 2015;21:55-76. https:// doi.org/10.7227/JACE.21.2.5.

24. Monika M, Aswini P, Parthasarathy K. Effectiveness of in Service Training on ISO 18001 Certification among Industrial Employees. 2017.

25. Chai G-M. An analysis of the determinants of employment and wage of new college graduates. Korean Journal of Social Welfare. 2007;59:35-61.

26. Wolbers MH. Job mismatches and their labour-market effects among school-leavers in Europe. European Sociological Review. 2003;19:249-66.

27. Lee $\mathrm{S}$, Jung S. A study on factors affecting the employment and the willingness to work of people with disabilities. Disability \& Employment. 2016:26:41-66.

28. Bae SW, Yun S, Lee YS, Yoon J-H, Roh J, Won J-U. Income changes due to disability ratings and participation in economic activities caused by industrial accidents: a population-based study of data from the Fourth Panel Study of Workers' Compensation Insurance (PSWCI). International journal of environmental research and public health. 2018;15:2478.

29. Jeong I, Park JB, Kim HR, Yoon J-H, Won J-U, Roh J. Impacts of return-towork type and period on job retention in workers with occupational injuries and diseases. Journal of Korean medical science. 2017;33:e2.

30. Seok H, Yoon J-H, Roh J, Kim J, Kim Y-K, Lee W, et al. The association between subjective socioeconomic status and health inequity in victims of occupational accidents in Korea. Journal of occupational health. 2016:160168-OA.

31. Choi W-S, Kim B-K, Kim K-D, Moon O-K, Yeum D-M. Impact of the number of painful stimuli on life satisfaction among Korean industrial accident workers completing convalescence: dual mediating effects of self-esteem and sleeping time. Industrial health. 2016;54:460-8.

32. Seok H, Yoon J-H, Lee W, Lee J-H, Jung PK, Roh J, et al. The perceived socioeconomic status is an important factor of health recovery for victims of occupational accidents in Korea. J Korean Med Sci. 2016;31:164-70.

33. Corbière $M$, Renard M, St-Arnaud L, Coutu M-F, Negrini A, Sauvé G, et al. Union perceptions of factors related to the return to work of employees with depression. Journal of occupational rehabilitation. 2015:25:335-47.

34. Shi Q, Sinden K, MacDermid JC, Walton D, Grewal R. A systematic review of prognostic factors for return to work following work-related traumatic hand injury. Journal of Hand Therapy. 2014;27:55-62.

35. Lee S-J. The return-to-work system of the industrially injured workers in Korea. J Vocat Rehabil. 2011;20:1-34.

36. Park SK. Successful return to work and related factors among Job injured workers in Korea. J Rehabil Res. 2012;16:293-318. 
37. Hamer H, Gandhi R, Wong S, Mahomed NN. Predicting return to work following treatment of chronic pain disorder. Occupational medicine. 2013; 63:253-9.

38. Tadesse S, Israel D. Occupational injuries among building construction workers in Addis Ababa, Ethiopia. Journal of Occupational Medicine and Toxicology. 2016;11:16.

\section{Publisher's Note}

Springer Nature remains neutral with regard to jurisdictional claims in published maps and institutional affiliations.

- fast, convenient online submission

- thorough peer review by experienced researchers in your field

- rapid publication on acceptance

- support for research data, including large and complex data types

- gold Open Access which fosters wider collaboration and increased citations

- maximum visibility for your research: over $100 \mathrm{M}$ website views per year

At $\mathrm{BMC}$, research is always in progress. 